\title{
Basic Swimming Style Crawl Engineering Skills Survey in Athletes Ages 10-12
}

\author{
Puput Widodo ${ }^{\text {a }}$, Fatma Zainul Yunida ${ }^{\text {b }}$ \\ ${ }^{a, b}$ Sports Education, Faculty of Teacher Training and Education, Universitas Ma'arif Nahdlatul \\ Ulama, Indonesia \\ puputwidodo72@gmail.com $^{\text {a }}$, fatmazainulyunida@gmail.com ${ }^{\text {b }}$
}

\begin{abstract}
This study aims to: 1 .To know the basic technique skills of crawl style swimming in the Kebumen swimming club association students. 2. Knowing the factors of difficulty experienced by students in learning the basic motion skills of crawl style swimming 3. Students are able to apply the basic movements of swimming with the right steps. This research was conducted on the students of the Kebumen swimming club association in Gossi Kebumen. The research plan is carried out in November 2021. The sample referred to in this study is 20 students in the 10-12 year age group who take part in basic swimming skills training. Descriptive data analysis was entered to get an overview of the data including the average, standard deviation, maximum data, minimum data, range, frequency table and graphs. Based on the results of the research that has been carried out, it can be concluded: 1 . Freestyle swimming skills measured using a stopwatch on students aged 10-12 years at the swimming club association in Kebumen showed that $50 \%$ of students had very poor swimming skills, $25 \%$ students have poor swimming skills and $25 \%$ of students have sufficient skills. 2. The category of skills that dominates the most in students is very low ability. Contributing to further research is to conduct research on more intense exercises on crawl swimming style techniques need to be done by athletes and also strategies to improve the ability of athletes in crawl style swimming.
\end{abstract}

Keywords: Swimming, Crawl Style, Basic Swimming Technique.

\begin{abstract}
Abstrak
Penelitian ini bertujuan untuk: 1. Mengetahui keterampilan teknik dasar renang gaya crawl pada atlet perkumpulan club renang Kebumen. 2. Mengetahui faktorfaktor kesulitan yang dialami atlet dalam belajar keterampilan gerak dasar renang gaya crawl 3. Atlet mampu menerapkan dasar gerak renang dengan langkah yang benar. Penelitian ini dilakukan pada atlet perkumpulan club renang Kebumen di Gossi Kebumen. Rencana penelitian dilakukan pada bulan November 2021. Sampel yang dimaksud dalam penelitian ini adalah 20 atlet kelompok usia 10-12 tahun yang mengikuti pelatihan keterampilan dasar renang. Analisis data secara deskriptif dimasukkan untuk mendapatkan gambaran umum data meliputi ratarata, standar deviasi, data maksimum, data minimum, range, table frekuensi dan grafik. Berdasarkan hasil penelitian yang telah dilakukan, maka dapat disimpulkan:1.Ketrampilan renang gaya bebas yang diukur menggunakan stopwatch pada atlet kelompok usia 10-12 tahun pada perkumpulan club renang di Kebumen didapatkan hasil bahwa 50\% atlet memiliki ketrampilan renang yang
\end{abstract}


sangat kurang, $25 \%$ atlet memiliki ketrampilan renang kurang dan $25 \%$ atlet memiliki ketrampilan yang cukup. 2. Kategori ketrampilan yang paling mendominasi pada atlet adalah kemampuan sangat kurang. Kontribusi untuk penelitian selanjutnya yaitu agar melakukan penelitian tentang Latihan yang lebih intens mengenai teknik gaya renang crawl perlu dilakukan oleh atlet dan juga strategi guna meningkatkan kemampuan atlet dalam renang gaya crawl.

Kata kunci: Renang, Gaya Crawl, Teknik Dasar Renang.

\section{Introduction}

Sports have many functions, namely for training, educational tools, livelihoods, cultural media, spectacle materials, health coaching facilities, diplomacy and no less important as the pride of a country or nation (Burhaein, Tarigan, Budiana, Hendrayana, \& Phytanza, 2021; Phytanza, Burhaein, \& Pavlovic, 2021; Sutopo \& Misno, 2021). The main goal is the human being as a whole, both spiritually and physically. Sport has now grown into a phenomenon that covers all levels of society in the world (Irawan \& Limanto, 2021; Putra, Purwanto, \& Burhaein, 2021; Widiyono \& Mudiono, 2021). Through sports, personal ambitions and achievements and nations can be lifted to an honorable place. Through sports also good relations between nations can be established (Azizah \& Sudarto, 2021; Burhaein, Ibrahim, \& Pavlovic, 2020; Widodo \& Najibuzzamzam, 2021).

Exercise starts from the need and encouragement in humans to do physical activity, develop functional abilities, skills and speed of organs (Blair, Lamonte, \& Nichaman, 2018; Burhaein, 2017; Purwanto, Lumintuarso, \& Burhaein, 2021). Almost all countries pay attention to sports. This is because sports not only serve to get freshness alone, but sports can also contribute in shaping human character (Burhaein, Demirci, Lourenço, Németh, \& Phytanza, 2021; Engan \& Sæther, 2018; Pramantik \& Burhaein, 2019). Even in turn, sporting achievements themselves can uphold the name and dignity of the nation because sports are one of the things that make the song and the national flag can be flown in countries other than the arrival of the president.

Swimming is one of the sports that are much in demand by the public, especially teenagers and children, therefore in Indonesia, especially in big cities there are many swimming pools that can be utilized by the public to improve fitness and sports achievements (Meggs \& Chen, 2018). Swimming is also one of the sports that requires a pattern of hand and foot movements that must be done at the same time so that it can float and slide forward from one place to another (Susanto, 2017). The combination of feet and hands and breathing techniques combined with coordination of movements while swimming can create more efficient, effective movement results and good swimming.

This water sport is good for the development of the body as well as heart and lung health. Meanwhile, the ability of children to swim from an early age, especially at the age of 5 10 years, is influenced by the factors of understanding parents about how important it is to introduce water sports well, correctly, safely (Phytanza \& Burhaein, 2019; Susanto, 2017). Therefore, it is not wrong if the sport of swimming in its development so far can be accepted by the community. Based on the numbers of matches, swimming groups there are 4 (four) types of swimming styles that are competed, namely breaststroke swimming, freestyle crawl swimming, backstroke swimming, butterfly stroke swimming (Aleksandrovic, Jorgic, Block, \& Jovanovic, 
2015; Susanto, 2017).

The above swimming style has several basic techniques, namely: breathing, sliding, floating, body position, foot movement, hand movement, start, reversal and finish. To get maximum results, each basic technique needs to be coordinated properly and well (Fradejas \& Espada-Mateos, 2018; Susanto, 2017). The coordination referred to here is the incorporation of several basic techniques that are assembled into one form of exercise. Swimming coordination exercises can also be done with many variations of exercises, for example: by using tools, without tools, in pairs and so on.

Achievement in the sport of swimming, especially in terms of freestyle many aspects that must be considered one of them is arm muscles and hand thrust in freestyle swimming, in this case to improve achievement and good results done by mastering techniques and practicing programmatically, also with physical exercise or media to increase the speed of freestyle swimming.

Many factors cause the swimmer to fail in achieving maximum results and what should be considered is that the arm muscles greatly affect the speed when swimming 25 meters of the basic movement of the hands in freestyle (crawl) is an important thing in achieving swimming achievements, because it allows athletes to go forward in a stable position and record his time in pole position on the list. The best swimmers (Caputo et al., 2018; Susanto, 2017).

Based on the observations and observations of researchers on the field of Kebumen swimming athletes, most athletes still have difficulty applying the freestyle of swimming with the correct position. All athletes in this swimming club have learned lessons about the entire style of swimming, and a further understanding of the technique (Phytanza \& Burhaein, 2020; Smith, 2005).

Researchers also interviewed coaches about the difficulties experienced by athletes at this club who are on average 5-10 years old. Some of the difficulties that are still experienced by these athletes make researchers interested in conducting research on athletes who are quite a lot and have different swimming skills and the difficulty of practicing the coordination of swimming crawl style well. From the description above, the author is interested in conducting research with the title "Survey of Basic Techniques of Swimming Style Crawl On Athletes Association swimming club in Kebumen.

\section{Research Methodology}

\subsection{Participants}

This study involved swimming club athletes in Kebumen Regency, Indonesia. However, of these athletes, not all of them were participants in the study. Determination of screening participants using purposive sampling techniques (Fraenkel, Wallen, \& Hyun, 2012; Toomela, 2010). Sample criteria include 1) Swimming athletes aged 10-12;2) Be active in training at the club, and; 3) Willing to be a participant in the study. Based on these criteria, the participants of this study obtained 20 athletes aged $10-12$ years to be studied.

\subsection{Research Design}

The design of this study is quantitative descriptive research. The method used in this study is a survey method using data retrieval techniques with questionnaires as measurement 
techniques (Arikunto, 2013; Fraenkel et al., 2012). This research aims to find out the basic engineering skills of crawl style swimming in Kebumen swimming club athletes.

\subsection{Research Instruments}

Quantitative research makes instruments a determinant in measurement (Burhaein, Tarigan, \& Phytanza, 2020; Sugiyono, 2015). Based on this opinion, it can be concluded that the instrument in this study is the researcher himself who has been equipped with a set of theories and data cards that contain techniques and forms of assessment of aspects of knowledge and skills. The instrument is validated by validation of content or content by experts or expert judgement in this case carried out by PJOK teaching experts.

\subsection{Data Collection Techniques}

In data collection it is very important to pay attention to the rules so that it requires certain techniques in its collection (Fraenkel et al., 2012; Phytanza \& Burhaein, 2020). In relation to the method of data collection in this study, the tests and measurements in question to determine the strength of arm muscles, limb muscle strength and freestyle swimming speed. There are three stages in data collection techniques, namely preparation, implementation, and completion.

The first stage is the research preparation stage. At this stage there are three things to consider. These three things are 1) In order to get the population, researchers apply for research permits to the Kebumen swimming club association; 2) Take data on the characteristics and number of participants, and; 3) The research place was conducted at Gossi Kebumen Swimming Pool. The second stage is the research stage. At this stage there are two things to consider. Both of these are 1) Before the research is carried out, the athletes of the Kebumen swimming club association are collected and then re-recorded. After that warm up; 2) For the implementation of research using data collection techniques using test and measurement techniques, namely the number of crawl force swimming speed results using a stopwatch.

The last stage is the completion of the research. At this stage the research data that has been obtained is then processed in order to analyze and interpret the data so that its readability is more communicative than presented in the form of raw data.

\subsection{Data Analysis Techniques}

Analytical techniques in this study use quantitative descriptive analysis techniques (Fraenkel et al., 2012; Mylsidayu, 2021). The data in this study is a form of numbers including data from the speed of freestyle swimming. But the data that has been collected is still rough data. Then the data collected needs to be analyzed in a descriptive and inferential statistical basis for the purposes of submitting research hypotheses. Data analysis is descriptively included to get an overview of the data including averages, standard deviations, maximum data, minimum data, range, frequency tables and graphs. 


\section{Results and Discussions}

\subsection{Results}

Table 1. Crawl Style Swimming Capability Data

\begin{tabular}{|c|c|c|c|c|}
\hline No & $\begin{array}{c}\text { Athlete's } \\
\text { Name }\end{array}$ & Age & Origin of the Club & Time (seconds) \\
\hline 1. & Zaky & 10 & Gets & 26,02 \\
\hline 2. & Sasha & 10 & Gets & 27,18 \\
\hline 3. & Malik & 10 & Kembar & 26,16 \\
\hline 4. & Ayya & 10 & Kembar & 29,33 \\
\hline 5. & Nabhan & 10 & Dolpin & 29,77 \\
\hline 6. & Ilham & 11 & Dolpin & 29,66 \\
\hline 7. & Wisyam & 11 & Gets & 31,16 \\
\hline 8. & Hafid & 11 & Gets & 27,50 \\
\hline 9. & Naufal & 11 & Kembar & 26,20 \\
\hline 10. & Davin & 11 & Kembar & 27,68 \\
\hline 11. & Rangga & 11 & Dolpin & 27,50 \\
\hline 12. & Intan & 11 & Dolpin & 27,68 \\
\hline 13. & Khanza & 12 & Gets & 31,16 \\
\hline 14. & Anggun & 12 & Gets & 30,18 \\
\hline 15. & Tiara & 12 & Gets & 29,44 \\
\hline 16. & Okta & 12 & Kembar & 32,01 \\
\hline 17. & Ina & 12 & Kembar & 30,06 \\
\hline 18. & Aisyah & 12 & Dolpin & 26,29 \\
\hline 19. & Sasmita & 12 & Dolpin & 28,50 \\
\hline 20. & Ikhbar & 12 & Dolpin & 29,04 \\
\hline
\end{tabular}

Source: Primary Data 2021

The results of calculating the crawl style swimming ability data to cover a distance of 25 meters of kebumen swimming club association athletes resulted in a mean $=28,626$, median $=28.77$, mode $=31.16$ and standard deviation $=1.82$. The smallest score is 26.02 and the highest score is 32.01 . The results of the crawl-style swimming ability test for athletes aged 1012 years with a distance of 25 meters can be described in the determination of speed measurements as in Table 2.

Table 2. Crawl Style Swimming Capability Categorization Data

\begin{tabular}{lcccc}
\hline No & Interval & Category & Frequency & $\%$ \\
\hline 1 & $\leq 22,38$ & Very Good & - & - \\
\hline 2 & $22,39-24,85$ & Good & - & - \\
\hline 3 & $24,86-27,33$ & Medium & 5 & $25 \%$ \\
\hline 4 & $27,34-29,80$ & Low & 5 & $25 \%$ \\
\hline 5 & $\geq 29,81$ & Very Low & 10 & $50 \%$ \\
\hline & & 20 & $100 \%$ \\
\hline
\end{tabular}

Source: Primary Data 2021 
Based on the table above it can be known that athletes with enough ability as many as 5 people (25\%), less ability as many as 5 people (25\%) and very less ability is 10 people (50\%). The above categorization is in accordance with the formulation proposed by Arikunto (2013). The crawl style swimming village graph of athletes of the 10-12 year age group of swimming club associations in Kebumen can be seen in the diagram in Figure 1.

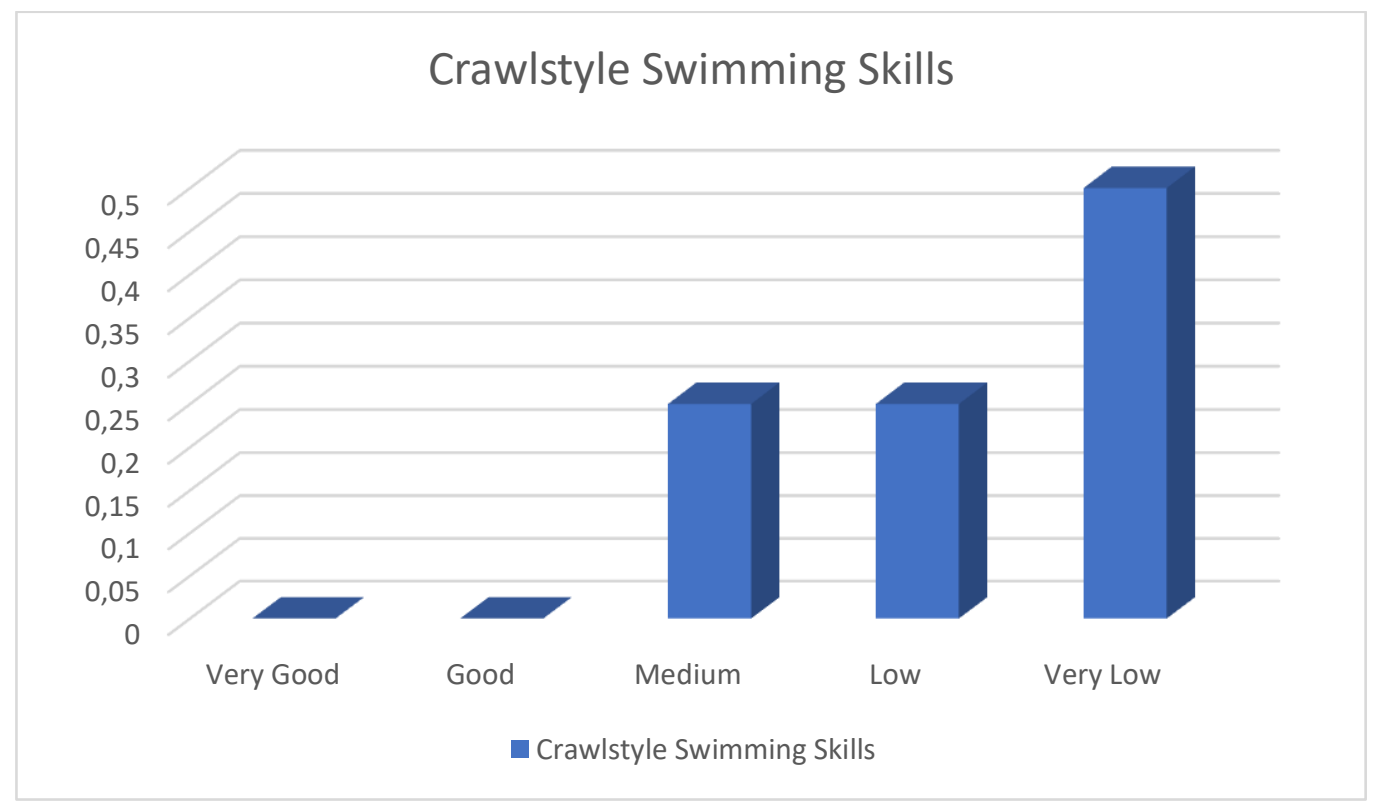

Figure 1. Crawlstyle swimming skills categorization diagram

\subsection{Discussions}

Swimming is a sport that is done in water that involves almost all parts of the body to move. This swimming activity can be used for recreation and also water sports. Swimming is used when moving from one place to another in the water, fishing, bathing, or doing water sports (Phytanza \& Burhaein, 2019; Septiawan, 2018). Swimming makes the body healthy because almost all limbs are used when swimming.

In the sport of swimming there are many various styles in doing swimming movements, one of which is freestyle (crawl). Freestyle (crawl) is a force that movements his legs up and down alternating left leg and right leg, the movement of his arms rowing one by one alternating between the left arm with the right arm while the position of his body is face down. Freestyle (crawl) in the sport of swimming is one style that is considered difficult to do by most athletes (Stan, 2012; Susanto, 2017). Based on the research steps that have been done, the final product is obtained in the form of swimming skills test instruments of athletes aged 10-12 years.

Based on the results of research related to crawl style swimming skills, showed that athletes with enough ability as many as 5 people (25\%), less ability as many as 5 people (25\%) and very less ability is 10 people (50\%). The very less category is the most amount It can be an indicator of the difficulty that athletes experience in freestyle swimming. Based on the results of the athlete's response, it can be concluded that the swimming skills test instrument product can be done as a measuring tool for swimming skills tests. This is in accordance with opinion of Bompa \& Buzzichelli (2019) that to learn swimming movements ideally has started between the ages of 3-7 years, at the age of 10-12 years is the age for specialization. However, children's reaction to swimming skills depends on several factors such as age, physical characteristics, 
language, and cognitive development, level of socialization, and emotional factors (Cesari, 2000: 53) The success of developing swimming skills test products aged 10-12 years is inseparable from the child's motor readiness that is mature enough.

As revealed Robert S. Weinberg. \& Dainiel Gould (2018) That motor development means the development of physical movement control through the activities of the nerve center, nerves, and muscles that are mature and coordinated. Such control comes from the development of reflection and mass activities that exist at birth time. It is also in accordance with the preoperational stage (2-7 years) which is a stage characterized by the development of semiotic functions with the formation of subjective and concrete early mental symbols (Burhaein, 2017; Schunk, 2014). Based on the results of research observations there are several factors of difficulty experienced by athletes, including difficulty in foot movements when swinging, short movements and rudimentary head position.

The above results mean that athletes themselves have difficulty in mastering swimming style crawl. Physically most athletes still do not have the strength and flexibility of the body is good in doing swimming style crawl. This is because to do swimming crawl style requires stamina. In addition, psychologically most athletes are still afraid to do swimming. If psychologically athletes are still afraid and there is no high willingness to do swimming, it will affect their basic movement skills. This is because athletes will hesitate in doing swimming. Talent and motivation are related to a person's mentality, in mastering swimming style crawl must have a good mentality and brave. Therefore, athletes must have training with seriousness and teachers must be able to cause pleasure to crawl style swimming and provide motivation in training. For athletes who feel less motivation will feel pessimistic to follow crawl-style swimming training and it will be an obstacle. While fatigue is related to the physical athlete, it must be trained regularly.

There are several factors that influence the results of crawl style swimming skills, which are stated by Susanto (2017) The specific problems in question are: floating, gliding, leg movement, arm movement, breathing method. But if outlined, the factors that affect the outcome of swimming skills are very complex and fundamental in learners. Among them can be classified into two large groups that are spelled out in more detail and complex.

The first is the athlete's internal factor. Internal factors or that appear in the learner itself can be the subject of existing and basic problems, namely: Basic skill factors such as leg movement, arm movements, body position, breath movements, and coordination of overall movements. Physical condition: health, injuries and cramps. Psychological conditions: the level of anxiety about water or certain traumas as well as the willpower, perseverance and focus on lectures and the motivation of mahaatlet towards crawl-style swimming learners.

The second is external factors. The next factor is external factors or from outside learners, this also affects the results of learners' skills such as: Lecture infrastructure facilities: swimming pools and learning aids. Method of learning: a variety of teaching techniques of lecturers and the suitability of the material taught. Lecture hours are the time used to learn basic swimming crawl style during lectures.

\section{Conclusions}


Based on the results of research that has been conducted, the researchers concluded that freestyle swimming skills measured using stopwatches in athletes aged 10-12 years at the association of swimming clubs in Kebumen obtained the result that $50 \%$ of athletes have very less swimming skills, $25 \%$ of athletes have less swimming skills and $25 \%$ of athletes have enough skills. This shows that the most dominating skill category in athletes is very lacking ability. Based on the findings above, the implications of these findings on swimming learning can be known the extent of the ability of athletes in doing swimming style crawl and identifying things that are still difficult athletes in this style Testing this style of swimming can be used by coaches in order to find solutions to the difficulties experienced by athletes in applying this style of swimming. This can later be a solution for the coach to improve the ability of his athletes. Contributing to further research is to conduct research on more intense exercises on crawl swimming style techniques need to be done by athletes and also strategies to improve the ability of athletes in crawl style swimming.

\section{References}

Aleksandrovic, M., Jorgic, B., Block, M., \& Jovanovic, L. (2015). the Effects of Aquatic Activities on Physical Fitness and Aquatic Skills in Children With Autism Spectrum Disorders: a Systematic Review. Life Skills Journal of Psychology, 13(3), 351-362.

Arikunto, S. (2013). Prosedur Penelitian Suatu Pendekatan Praktik. Jakarta: Asdi Mahasatya.

Azizah, A. R., \& Sudarto, E. P. (2021). Minat Mengikuti Ekstrakurikuler Bola Voli Siswa Smp Negeri 3 Satu Atap Karangsambung Kecamatan Karangsambung Tahun Ajaran 2019/2020. JUMORA: Jurnal Moderasi Olahraga, 1(01), 35-44. https://doi.org/10.53863/mor.v1i01.132

Blair, S. N., Lamonte, M. J., \& Nichaman, M. Z. (2018). The evolution of physical activity recommendations: how much is. American Journal Clinical Nutrition, 79(5), 913-920. https://doi.org/10.1093/ajen/79.5.913S

Bompa, T. O., \& Buzzichelli, C. (2019). Periodization Theory and Methodology of Training (Sixth). United States.

Burhaein, E. (2017). Aktivitas Fisik Olahraga untuk Pertumbuhan dan Perkembangan Siswa SD. Indonesian Journal of Primary Education, 1(1), 51-58. https://doi.org/10.17509/ijpe.v1i1.7497

Burhaein, E., Demirci, N., Lourenço, C. C. V., Németh, Z., \& Phytanza, D. T. P. (2021). Coping with the COVID-19 pandemic: the role of physical activity. An international position statement. International Sports Studies, 43(1), 52-70. https://doi.org/10.30819/iss.43-1.05

Burhaein, E., Ibrahim, B. K., \& Pavlovic, R. (2020). The Relationship of Limb Muscle Power, Balance, and Coordination with Instep Shooting Ability: A Correlation Study in Under-18 Football Athletes. International Journal of Human Movement and Sports Sciences, 8(5), 265-270. https://doi.org/10.13189/saj.2020.080515

Burhaein, E., Tarigan, B., Budiana, D., Hendrayana, Y., \& Phytanza, D. T. P. (2021). Physical Activity Level of Students with Disabilities during COVID-19 Pandemic. Jurnal Pendidikan Jasmani Dan Olahraga, 6(2), 19-21. https://doi.org/10.17509/jpjo.v6i2.38547 
Burhaein, E., Tarigan, B., \& Phytanza, D. T. P. (2020). The experience and understanding of the K-13 curriculum implementation of Indonesian teachers of Adapted Physical Education (APE). International Sports Studies, 42(e), 29-42. https://doi.org/10.30819/iss.42-e.04

Caputo, G., Ippolito, G., Mazzotta, M., Sentenza, L., Muzio, M. R., Salzano, S., \& Conson, M. (2018). Effectiveness of a Multisystem Aquatic Therapy for Children with Autism Spectrum Disorders. Journal of Autism and Developmental Disorders, 48(6), 1945-1956. https://doi.org/10.1007/s10803-017-3456-y

Engan, C., \& Sæther, S. A. (2018). Goal orientations, motivational climate and stress perception in elite junior football players: A comparison of club levels. Journal of Physical Education and Sport, 18(1), 107-113. https://doi.org/10.7752/jpes.2018.01014

Fradejas, E., \& Espada-Mateos, M. (2018). How do psychological characteristics influence the sports performance of men and women? A study in school sports. Journal of Human Sport and Exercise, 13(4), 858-872. https://doi.org/10.14198/jhse.2018.134.13

Fraenkel, J. R., Wallen, N. E., \& Hyun, H. H. (2012). How to design and evaluate research in education. New York: Mc Graw Hill.

Irawan, Y. F., \& Limanto, D. (2021). Pengaruh Kecerdasan Emosi dan Kesiapan Diri Terhadap Pertandingan Pada Pemain Walet Muda Futsal Academy Kebumen Tahun 2020. JUMORA: Jurnal Moderasi Olahraga, I(01), 18-26. https://doi.org/10.53863/mor.v1i01.130

Meggs, J., \& Chen, M. A. (2018). Mental toughness and attributions of failure in high performing male and female swimmers. Journal of Human Sport and Exercise, 13(2), 276-284. https://doi.org/10.14198/jhse.2018.132.03

Mylsidayu, A. (2021). Stress level of physical education students: How to do the learning during the covid-19 pandemic? Journal Sport Area, 6(1), 148-160. https://doi.org/10.25299/sportarea.2021.vol6(1).5729

Phytanza, D. T. P., \& Burhaein, E. (2019). Aquatic activities as play therapy children autism spectrum disorder. International Journal of Disabilities Sports and Health Sciences, 2(2), 64-71. https://doi.org/10.33438/ijdshs.652086

Phytanza, D. T. P., \& Burhaein, E. (2020). The Effects of Tenure, Teacher Certification, and Work Motivation on Special Needs Teacher Performance. Universal Journal of Educational Research, 8(9), 4348-4356. https://doi.org/10.13189/ujer.2020.080962

Phytanza, D. T. P., Burhaein, E., \& Pavlovic, R. (2021). Gross Motor Skills Levels in Children with Autism Spectrum Disorder during the COVID-19 Pandemic. International Journal of Human Movement and Sports Sciences, 9(4), 738-745. https://doi.org/10.13189/saj.2021.090418

Pramantik, I. A. D., \& Burhaein, E. (2019). A Floor Time Approach to Improve Learning Outcomes of the Body Roll to the Side in Adaptive Physical Education Learning: Classroom Action Research Study on Two Cerebral Palsy Students. International Journal of Disabilities Sports and Health Sciences, 2(2), 45-53. https://doi.org/10.33438/ijdshs.652061

Purwanto, P., Lumintuarso, R., \& Burhaein, E. (2021). Impact of Running Techniques through 
the Sprint Ability in Athletes during the COVID-19 Pandemic. International Journal of Human Movement and Sports Sciences, 9(4), 717-724. https://doi.org/10.13189/saj.2021.090416

Putra, Y. M., Purwanto, S., \& Burhaein, E. (2021). Effect of Limb Muscle Power Training with Leaps on Athlete's Speed during the COVID-19 Pandemic. International Journal of Human Movement and Sports Sciences, 9(3), 461-465. https://doi.org/10.13189/saj.2021.090310

Robert S. Weinberg. \& Dainiel Gould. (2018). Foundations of Sport and Exercise Psychology. https://doi.org/10.1097/00005768-200408000-00029

Schunk, D. H. (2014). Learning theories: an educational perspective. London: Pearson.

Septiawan, F. (2018). Pelaksanaan Pembelajaran Akuatik untuk Anak Cerebral Palsy di SLB N Pembina Yogyakarta. Widia Ortodidaktika, 7(5), 438-448.

Smith, M. (2005). Literacy and Augmentative and Alternative Communication. Burlington: Elsevier Academic Press.

Stan, A. E. (2012). The benefits of participation in aquatic activities for people with disabilities. Sports Medicine Journal / Medicina SportivÃ $\phi, 8(1)$, 1737-1742. Retrieved from http://search.ebscohost.com/login.aspx?direct=true \&db=sph\&AN=74249978\&site=ehostlive

Sugiyono. (2015). Metode Penelitian Pendidikan Pendekatan Kuatitatif, Kualitatif, dan R\&D. Bandung: Alfabeta.

Susanto, E. (2017). Keselamatan di Air (Water Safety). Yogyakarta: UNY Press.

Sutopo, W. G., \& Misno. (2021). Analisis Kecepatan Tendangan Sabit Pada Pesilat Remaja Perguruan Pencak Silat Tri Guna Sakti Di Kabupaten Kebumen Tahun 2020. JUMORA: Jurnal Moderasi Olahraga, 1(01), 27-34. https://doi.org/10.53863/mor.v1i01.131

Toomela, A. (2010). Quantitative methods in psychology: Inevitable and useless. Frontiers in Psychology, 1(JUL), 1-14. https://doi.org/10.3389/fpsyg.2010.00029

Widiyono, I. P., \& Mudiono. (2021). Keterampilan Dasar Futsal Peserta Ektrakurikuler di SMK Ma'arif 1 Kebumen Tahun Ajaran 2019/2020. JUMORA: Jurnal Moderasi Olahraga, 1(01), 10-17. https://doi.org/10.53863/mor.v1i01.129

Widodo, P., \& Najibuzzamzam, A. (2021). Perbandingan Model Pembelajaran Daring Dan Tatap Muka Penjaskes Mts Darussa'adah Pada Masa Pandemi Tahun Ajaran 2019/2020. JUMORA: Jurnal Moderasi Olahraga, 1(01), 1-9. https://doi.org/10.53863/mor.v1i01.128 